of duty-free trade and directions for its improvement]. Yurydychnyi naukovyi elektronnyi zhurnal. № 5. P. 104-108. doi: https://doi.org/10.32782/2524-0374/2019-5/23

5. Mytnyi kodeks Ukrainy vid 13 bereznia 2012 roku № 4495-VI [Customs Code of Ukraine of March 13, 2012 № 4495-VI]. URL: https://zakon.rada.gov.ua/laws/show/4495-17\#Text.

6. Rehlament Yevropeiskoho Parlamentu i Rady (EU) № 952/2013 vid 9 zhovtnia 2013 roku pro vstanovlennia Mytnoho kodeksu Soiuzu [Regulation (EC) № 952/2013 of the European Parliament and of the Council of 9 October 2013 establishing the Union Customs Code]. URL: https://zakon.rada.gov.ua/laws/show/ru/984 009-13\#Text.

7. European Commission. Taxation and Custom Union (2020). URL: https://ec.europa.eu/taxation_customs/business/ customs-procedures_en.

8. Bezmytni taryfni kvoty ta yikh vykorystannia (2020) [Duty-free tariff quotas and their use]. Yevrointehratsiinyi portal. URL: http://eu-ua.org/zona-vilnoi-torhivli/bezmytni-taryfni-kvoty-ta-yihnie-vykorystannia.

9. Mytni pytannia ta spryiannia torhivli (2020) [Customs issues and trade facilitation]. Yevrointehratsiinyi portal. URL: http://eu-ua.org/yevrointehratsiia/mytni-pytannia-ta-spryiannia-torhivli.

\title{
DOI https://doi.org/10.51647/kelm.2020.3.1.43
}

\section{ПРАВО НА СПРАВЕДЛИВИЙ СУД ТА ТЛУМАЧЕННЯ АДМІНІСТРАТИВНО-ДЕЛІКТНИХ ПРАВОВИХ НОРМ}

\author{
Владислав Ліпинський \\ кандидат юридичних наук, доиент, \\ директор \\ Навчально-наукового інституту права та міжнародно-правових відносин \\ Університету митної справи та фінансів (Дніпро, Украӥна) \\ ORCID ID: 0000-0002-4373-3330
}

\begin{abstract}
Анотація. За допомогою нормативно-догматичного та системного методів наукового пізнання як комплекс взаємопов'язаних загальнообов'язкових юридичних стандартів досліджуються закріплені Конвенцією про захист прав людини і основоположних свобод гарантії справедливого судового розгляду з точки зору їх впливу на тлумачення адміністративно-деліктних правових норм. За підсумками дослідження обгрунтовується висновок про те, що одним 3 найбільш важливих завдань тлумачення адміністративно-деліктних правових норм у справах про адміністративні правопорушення із кримінально-правовою природою є забезпечення дотримання конвенційних гарантій справедливого судового розгляду, якими передбачено, зокрема: 1) змагальність судового розгляду та рівність його учасників, які вимагають того, щоб «кримінальне обвинувачення» під час адміністративно-деліктного судочинства підтримував прокурор або інша уповноважена посадова особа, а також того, щоб особа мала можливість ознайомитись з усіма матеріалами справи та можливість одержати докази за допомогою суду; 2) обгрунтованість судових рішень, що покладає на суд обов'язок оцінити доводи та докази особи, яка притягується до відповідальності, що можуть вплинути на висновок про іiї винуватість та адміністративно-деліктні наслідки вчиненого нею адміністративного правопорушення, керуючись при цьому стандартом доказування «поза розумним сумнівом»; 3) непорушність свободи від самовикриття, що унеможливлює визнання прийнятними доказів, які особа, яка притягується до відповідальності, створила під примусом юридичного обов'язку та загрозою санкцій за його виконання; 4) дотримання презумпції невинуватості, яка передбачає насамперед покладення тягаря доказування на сторону обвинувачення, тлумачення будь-яких сумнівів на користь обвинуваченого; 5) надання особі, яка притягується до відповідальності, часу і можливостей, необхідних для підготовки захисту, який полягає, зокрема у ознайомленні з висунутими обвинуваченнями та наявними доказами, а також у їх належній оцінці та визначенні шляхів захисту від обвинувачення, у тому числі з використанням допомоги адвоката.

Ключові слова: гарантії справедливого судового розгляду у справах про адміністративні правопорушення, законодавство про адміністративні правопорушення, право на справедливий суд, практика Європейського суду з прав людини, тлумачення адміністративно-деліктних правових норм.
\end{abstract}

\section{RIGHT TO A FAIR TRIAL AND ITS IMPLICATIONS FOR ADMINISTRATIVE TORT LAW INTERPRETATION}

\author{
Vladyslav Lipynskyi \\ Candidate of Legal Sciences, Associate Professor, \\ Director \\ Educational and Scientific Institute of Law and International Legal Relations \\ of the University of Customs and Finance (Dnipro, Ukraine) \\ ORCID ID: 0000-0002-4373-3330
}

\begin{abstract}
Availing on normative-dogmatic and systemic methods of scientific research as a set of interrelated universally binding legal standards the article studies the guarantees of a fair trial enshrined in the Convention for the Protection
\end{abstract}


of Human Rights and Fundamental Freedoms in terms of their impact on the interpretation of administrative tort law. The outcomes of the research make it possible to conclude that one of the most important tasks of interpretation of administrativetort legal rules in cases of administrative offenses of criminal nature is to ensure compliance with the fair trial guarantees, which requires, in particular: 1) the adversarial nature of the trial and the equality of its participants, which prescribes that a "criminal charge" during the administrative-tort proceedings must be upheld by a prosecutor or other authorized official, as well as that the person should be able to have access to all case materials and obtain evidence with the help of the court, except in cases where the evidence is not relevant to the case or the statement of their demand is not accompanied by a proper justification; 2) the proper reasoning of court decisions, which imposes an obligation on court, bearing in mind the "beyond reasonable doubt" standard of proof, to assess those arguments and evidence of the person prosecuted, which may affect the conclusion regarding his or her guilt and administrative-tort consequences of committed administrative offense; 3) right not to incriminate oneself, which makes it impossible to give weight to the evidence that the person prosecuted created under duress of legal obligation and the threat of sanctions for its enforcement; 4) compliance with the presumption of innocence, which provides, first of all, placing the burden of proof on the prosecution, the interpretation of any doubts in favour of the accused; 5) providing the person being prosecuted with the time and facilities necessary to prepare a defence, which consists, in particular, of reviewing the charges and available evidence, as well as of their proper assessment and determination of ways to defend against the prosecution, including the use of legal assistance.

Key words: guarantees of right to a fair trial in administrative sanctioning procedures, administrative tort legislation, interpretation of administrative tort law, right to a fair trial, European Court of Human Rights case-law.

\title{
PRAWO DO SPRAWIEDLIWEGO PROCESU SĄDOWEGO I WYKLADNI ADMINISTRACYJNO-DELIKTOWYCH PRZEPISÓW PRAWNYCH
}

\author{
Vladyslav Lipynskyi \\ kandydat nauk prawnych, docent, \\ dyrektor Naukowo-Dydaktycznego Instytutu Prawa i Międzynarodowych Stosunków Prawnych \\ Uniwersytetu Sprawy Celnej i Finansów, (Dniepr, Ukraina) \\ https://orcid.org/0000-0002-4373-3330
}

\begin{abstract}
Adnotacja. Za pomocą normatywno-dogmatycznych i systemowych metod wiedzy naukowej, jako kompleks powiązanych ze sobą obowiązkowych standardów prawnych, badane są ustalone w Konwencji o Ochronie Praw Człowieka i Podstawowych Wolności gwarancji sprawiedliwego postępowania sądowego pod względem ich wpływu na interpretację administracyjno-deliktowych norm prawnych. Na podstawie wyników badania, uzasadnia wniosek, że jednym z najważniejszych zadań interpretacji administracyjno-deliktowych norm prawnych w sprawach o wykroczeniach administracyjnych o naturze karno-prawnej jest zapewnienie zgodności konwencjonalnych gwarancji rzetelnego procesu sądowego, który przewiduje, w szczególności: 1) konkurencyjność postępowania i równości jego członków, które żądają tego, aby „oskarżenia” podczas administracyjno-deliktowego postępowania sądowego wspierał prokurator lub inny upoważniony funkcjonariusz, a także tego, aby dana osoba miała możliwość zapoznania się ze wszystkimi aktami sprawy i możliwość uzyskania dowodów za pośrednictwem sądu; 2) uzasadnienie orzeczeń sądowych, co nakłada na sąd obowiązek oceny argumentów i dowodów osoby pociągniętej do odpowiedzialności, mogących wpłynąć na wniosek o jej winę i konsekwencje deliktowe popełnionego przez nią wykroczenia administracyjnego, kierując się jednocześnie standardem dowodu „ponad uzasadnione wątpliwości”; 3) niezachwianie wolności od samowykrytycyzmu, co uniemożliwia uznanie akceptowalnych dowodów, które osoba pociągnięta do odpowiedzialności stworzyła pod przymusem obowiązku prawnego $i$ groźbą sankcji za jego wykonanie; 4) przestrzeganie domniemania niewinności, które polega przede wszystkim na nałożeniu ciężaru dowodu na stronę oskarżenia, interpretacji wszelkich wątpliwości na korzyść oskarżonego; 5) zapewnienie osobie pociągniętej do odpowiedzialności czasu i możliwości niezbędnych do przygotowania obrony, polegającej w szczególności na zapoznaniu się z przedstawionymi zarzutami i dostępnymi dowodami oraz ich właściwej ocenie i określeniu sposobów obrony przed zarzutem, w tym z wykorzystaniem pomocy adwokata.
\end{abstract}

Słowa kluczowe. Gwarancje sprawiedliwego postępowania sądowego w sprawach o wykroczenia administracyjne, prawo o wykroczeniach administracyjnych, prawo do sprawiedliwego procesu sądowego, praktyka Europejskiego Trybunału Praw Człowieka, wykładnia administracyjno-deliktowych przepisów prawnych.

Вступ. Динамічний та еволюційний розвиток практики тлумачення Конвенції про захист прав людини і основоположних свобод (Конвенції) Європейським судом з прав людини (ЄСПЛ) призводить до все більш широкого підпорядкування національного законодавства конвенційним стандартам. Зважаючи на це, невичерпною є актуальність для наукового співтовариства держав-учасниць цього міжнародно-правового документа спрямовувати наукові дослідження на грунтовне вивчення мінливого прецедентного права ЄСПЛ для формулювання наукомістких положень, висновків та рекомендацій щодо шляхів впливу правових позицій, виданих цією міжнародною судовою установою, на тлумачення всіх матеріально-правових та процесуальних норм права, що мають значення для забезпечення прав людини і основоположних свобод. Зокрема, порядок провадження у справах про адміністративні правопорушення вже зазнав значних змін у рамках його приведення у відповідність до практики ССПЛ, однак ними цей процес не має завершитись, адже, як показує зіставлення цих правових джерел, має місце значний простір для подальшого вдосконалення законодавства про порядок розгляду та вирішення справ про адміністративні правопорушення та більш повного дотримання ним конвенційних стандартів справедливого судового розгляду.

Основна частина. Основним дослідницьким завданням є визначення гарантій справедливого судового розгляду, які є застосовними під час притягнення до відповідальності за вчинення адміністративних право- 
порушень, з наведенням конкретних вимог, належне виконання яких забезпечить дотримання під час розгляду справ про адміністративні правопорушення конвенційного права на справедливий суд.

Матеріал і методи досліджень. Нормативно-правовою основою дослідження слугуватиме практика тлумачення та застосування Конвенції про захист прав людини і основоположних свобод Європейським судом 3 прав людини у частині, що впливає на тлумачення адміністративно-деліктного законодавства, яка опрацьовуватиметься з використанням нормативно-догматичного та системного методів наукового пізнання шляхом ії сприйняття як упорядкованого комплексу взаємопов'язаних юридичних стандартів, що є обов'язковими до дотримання під час правил провадження у справах про адміністративні правопорушення. Джерелознавчий аналіз охопить також декілька наукових праць та аналітичних досліджень, присвячених зазначеній частині практики ССПЛ, зокрема напрацювання М. Арслана, О. Бучинського та А. де Моур-ван Вугта. За підсумками дослідження буде синтезовано та систематизовано комплекс конкретних процесуальних вимог, належне виконання яких забезпечить дотримання під час розгляду справ про адміністративні правопорушення конвенційного права на справедливий суд.

Результати та їх обговорення. 3 огляду на значення для тлумачення та застосування адміністративноделіктних норм, найбільша увага має бути приділена процесуальним стандартам рівності та змагальності, умотивованості судових рішень, свободи від самовикриття, а також спеціальним вимогам про презумпцію невинуватості та право мати час і можливості, необхідні для підготовки захисту.

Так, фундаментальною процесуальною гарантією справедливого судового розгляду є забезпечення рівності та змагальності сторін. Розкриваючи зміст та значення цих універсальних засад судочинства, ЄСПЛ зазначає, що принцип рівності сторін у розумінні «справедливого балансу» між сторонами вимагає, щоб кожній стороні надавалась розумна можливість представити позицію у таких умовах, які не ставлять цю сторону у істотно невигідне становище порівняно із процесуальним опонентом. При цьому принцип змагальності процесу, за визначенням ЄСПЛ, означає, що кожній стороні повинна бути надана можливість ознайомитись з усіма доказами та зауваженнями, наданими іншою стороною, та відповісти на них (Дирекція юрисконсульта ЄСПЛ, 2013: 22).

Належне забезпечення змагальності сторін є неодмінною умовою впевненості сторін у тому, що здійснюється правосуддя, яке грунтується, зокрема, на усвідомленні того, що вони мали змогу висловити свої думки щодо кожного документа в матеріалах справи (Дирекція юрисконсульта ССПЛ, 2013: 23). 3-поміж іншого змагальність сторін у кримінальних провадженнях зумовлює необхідність для органів кримінального переслідування розкривати перед стороною захисту всі наявні у них докази, які можна використати як для обвинувачення, так і для виправдання особи. Водночас право сторони захисту на доступ до матеріалів провадження не є абсолютним. Наприклад, за підсумками дослідження практики ЄСПЛ під час розгляду адміністративних справ про порушення законодавства про захист економічної конкуренції, які характеризуються значною близькістю до кримінальних покарань, А. де Моур-ван Вугт зауважив, що у цих справах нерідко можуть мати місце конкуруючі інтереси, такі як захист особливо важливої ділової інформації, яка протистоїть праву обвинуваченого на повний та безперешкодний доступ до матеріалів провадження (де Моур-ван Вугт, 2012: 18).

На доповнення до вищевикладеного рівність та змагальність сторін передбачає надання їм можливостей збирати та подавати докази для їх дослідження та оцінки судом. Відмова заслухати будь-яких свідків сторони захисту або прийняти доказ для його дослідження є правомірною, якщо клопотання про допит свідка або долучення доказу не було обгрунтованим та доречним з точки зору предмета обвинувачення, національний суд оцінив важливість відповідних доказів для встановлення обставин справи та навів досить підстав для рішення не допитувати свідка під час судового розгляду або не досліджувати певний доказ, а також якщо це рішення суду не підриває загальну справедливість провадження (Абдуллаєв проти Азербайджану, заява № 6005/08, § 59-60).

Більше того, за загальновизнаними уявленнями про змагальність судового розгляду, які знайшли своє відображення і у прецедентній практиці ЄСПЛ, цей принцип покладає на суд обов’язок у кримінальних провадженнях сприяти стороні захисту у збиранні доказів за ії зверненням та за достатніх для цього підстав. Йдеться про те, що якщо сторона у справі виклала повне бачення того, якими конкретно доказами вона прагне послуговуватись та яке вони мають значення для вирішення справи, суд зобов'язаний сприяти цій стороні в отриманні цих доказів або навести обгрунтування відмови у забезпеченні доказів $з$ посиланням на обставини, через які ці докази не мають значення для вирішення справи. Інакше має вважатись, що суд не забезпечив стороні у справі можливість представити ії позицію та вплинути на шлях вирішення справи (Йокшаш проти Литви, заява № 25330/07, § 58). Водночас збирання викривальних доказів судом за власною ініціативою у рамках судового провадження у справі про адміністративне правопорушення є неприпустимим, адже за цих обставин суд виконує функції сторони обвинувачення, що не є сумісним із його призначенням щодо здійснення правосуддя та підриває рівне процесуальне становище сторін. За слушним зауваженням А. Діденка, що грунтується на аналітиці практики ЄСПЛ, збір судом доказів на підтвердження винуватості особи за відсутністю сторони обвинувачення у справах про адміністративне правопорушення свідчить про порушення права особи на неупереджений судовий розгляд, що знайшло підтвердження у висновках ССПЛ у справах «Карелін проти Росії» та «Малофєєва проти Росії». Автор також звертає увагу на те, що слід відзначити й відповідну практику Апеляційного суду міста Києва, яка чітко вказує, що витребування судом за власною ініціативою доказів у справах про адміністративні правопорушення не є правомірним, оскільки це становитиме порушення права на захист (особа не може належним чином підготуватися до захисту) та принципу рівності сторін процесу (оскільки особа має захищатися від обвинувачення, яке підтримується не стороною обвинувачення, а фактично судом) (Діденко, 2020). 
Іншим процесуальним правом, походження якого пов'язане із принципом рівності та яке докладно витлумачене у правових позиціях ЄСПЛ, є право на доступ до матеріалів справи, які включають усі документи та речі, які можуть використовуватись для встановлення чи спростування обставин справи. Це процесуальне право забезпечує можливість одержувати безперешкодний доступ до всіх матеріалів справи, у тому числі опрацьовувати їх, вільно знімаючи копії та створюючи нотатки. Водночас у межах дискреційних повноважень можуть встановлюватись обмеження часу для ознайомлення із матеріалами справи 3 дотриманням вимоги про достатність часу для підготовки захисту (Арслан, 2019: 48-49).

Таким чином, для забезпечення змагальності судового розгляду справи про адміністративне правопорушення та рівності іiі учасників судом мають вживатись заходи для того, щоб особа, яка притягується до відповідальності, мала можливість ознайомитись з усіма матеріалами справи, які можуть використовуватись для встановлення чи спростування обставин справи, а також можливість одержати докази за допомогою суду, крім випадків, коли докази не мають значення для вирішення справи або заява про їх витребування не супроводжується належним обгрунтуванням. Крім того, критичне значення має підтримання «кримінального обвинувачення» прокурором або іншою уповноваженою посадовою особою, що виключить необхідність для суду поєднувати у собі функції доказування винуватості особи та здійснення правосуддя, ставлячи під сумнів свою неупередженість та підриваючи змагальність процесу.

Поруч із наділенням національних судів повною юрисдикцією щодо обставин справи, дотримання рівності та змагальності під час судового провадження та іншими загальними гарантіями справедливого розгляду їх невід’ємним складником визнається умотивованість судових рішень.

Висловлюючись щодо значення вимоги про належне обгрунтування судових рішень для правосуддя, ЄСПЛ зазначає, що, хоча національний суд має певну свободу розсуду щодо вибору аргументів у тій чи іншій справі та прийняття доказів на підтвердження позицій сторін, суд зобов'язаний виправдати свої дії, навівши обгрунтування своїх рішень для того, щоб: 1) продемонструвати сторонам, що вони були почуті, а кожне питання, яке може мати поворотне значення для вирішення справи, грунтовно досліджене; 2) сторони мали можливість вжити ефективних заходів для перегляду судового рішення вищестоящою інстанцією; 3) забезпечувався публічний контроль за здійсненням правосуддя (Серявін та інші проти України, заява № 4909/04, § 58).

Конкретизуючи мінімальний необхідний обсяг обгрунтування судового рішення, ССПЛ дотримується позиції щодо того, що цей обсяг може змінюватись залежно від характеру рішення і має визначатись у світлі обставин справи. Суд не має давати відповідь на кожне порушене питання, однак з рішення має бути очевидно, що суд оцінив кожен аргумент та доказ, який може вплинути на рішення по суті справи, та висловив щодо них конкретну та зрозумілу позицію (Чжан проти України, заява № 6970/15, § 73). Інакше кажучи, у справах, що стосуються втручання у права, відображені у Конвенції, ССПЛ намагається встановити, чи $\epsilon$ підстави для рішень національних судів автоматичними чи стереотипними. Питання щодо відсутності обгрунтування судових рішень відповідно до пункту 1 статті 6 Конвенції, як правило, виникає, коли національні суди оминають належною увагою конкретне, релевантне та важливе питання, порушене стороною у справі (Дирекція юрисконсульта ЄСПЛ, 2020: 36).

Також існують підстави вважати, що, обгрунтовуючи судове рішення у провадженні, яке, зважаючи на природу правопорушення та передбаченого за його вчинення стягнення, є кримінальним, суд має керуватись стандартом доказування «поза розумним сумнівом». Таке доведення має випливати із сукупності ознак чи неспростовних презумпцій, досить вагомих, чітких і узгоджених між собою (Кобець проти України, заява № 16437/04, § 43). Конкретизуючи сутність цього стандарту доказування, зазначимо, що як розумним $є$ сумнів, який грунтується на певних обставинах та здоровому глузді, випливає зі справедливого та зваженого розгляду всіх належних та допустимих відомостей, визнаних доказами, або з відсутності таких відомостей i є таким, який змусив би особу втриматися від прийняття рішення у питаннях, що мають для неї найбільш вагоме значення (Авсар проти Туреччини, заява № 25657/94, § 282).

Таким чином, у справах про адміністративні правопорушення, на які поширюються гарантії справедливого судового розгляду, особливо важливим $\epsilon$ те, щоб суд оцінив доводи та докази особи, яка притягується до відповідальності, що можуть вплинути на висновок про іiі винуватість, та адміністративно-деліктні наслідки вчиненого нею адміністративного правопорушення. Також у цих справах про адміністративні правопорушення висновок про винуватість має грунтуватись на стандарті доказування поза розумним сумнівом, який передбачає те, що за підсумками судового розгляду має бути єдина версія, за якою особа, яка притягується до відповідальності, вчинила відповідне правопорушення, та яка здаватиметься розумній і безсторонній людині переконливою настільки, що виключатиме будь-які інші версії.

Справедливість судового розгляду у кримінальних провадженнях, як вони розуміються за термінологією практики тлумачення та застосування Конвенції, забезпечується також належним дотриманням національними судами та іншими компетентними органами свободи від самовикриття, яка випливає із сутності права на справедливий суд.

У ході наукового опрацювання проявів свободи від самовикриття у матеріально-правових, процедурних та процесуальних адміністративних відносинах насамперед висвітлюється зміст та призначення права не свідчити проти себе із посиланням на позицію ЄСПЛ про те, що це право вимагає, зокрема, від сторони обвинувачення в кримінальній справі не допускати - у спробах доведення своєї версії проти обвинуваченого - використання доказів, здобутих за допомогою методів примусу обвинуваченого чи тиску на обвинуваченого всупереч його волі. Також О. Бучинський за підсумками дослідження питань застосування 
практики Європейського суду з прав людини під час вирішення податкових спорів зазначив, що класичними випадками порушення зазначених прав вважаються зобов'язання особи давати показання під загрозою або внаслідок санкцій, зокрема зобов'язання особи до надання певних документів, про існування яких були припущення, але повної впевненості не було, тим самим примушення до передання доказів свого власного порушення, так само як і направлення податковим органом вимоги про надання документів, які можуть бути використані під час доведення вини платника податків у податковому правопорушенні під загрозою застосування до нього заходів відповідальності, у тому числі штрафу (Бучинський, 2019: 122-123).

Разом із тим ЄСПЛ дотримується думки про те, що суспільний інтерес, пов'язаний з регулюванням складних фінансових та економічних питань, безпідставно зневажався би, якщо гарантії справедливого судового розгляду перешкоджали б попереднім розслідуванням. Міжнародна судова установа визнає, що чимало адміністративних проваджень спрямовуються у тому числі на з'ясування підстав пред'явлення кримінального обвинувачення за виявлені правопорушення. Зважаючи на це, свобода від самовикриття не може захищати від примусового співробітництва з компетентними органами держави, крім випадку, коли від особи вимагається за власною волею створити проти себе докази. Однак, щоб компенсувати негативний вплив обов'язку співпрацювати на свободу від самовикриття, ЄСПЛ якомога більш зваженим рішенням вважає виключення доказів, отриманих шляхом примусу, у наступних кримінальних провадженнях (Канзал проти Сполученого Королівства, заява № 21413/02, § 27). Більше того, якщо стосовно особи, яка має співпрацювати із державними контрольно-наглядовими органами, вже розпочате кримінальне розслідування, свобода від самовикриття охоплює й адміністративне провадження. Водночас зобов'язання особи до співпраці з контрольно-наглядовим органом за цих умов допустиме, лише якщо законодавством передбачено виключення можливості використання доказів, отриманих у ході такого співробітництва, у рамках кримінального провадження (Мартінен проти Фінляндіï, заява № 19235/03, § 76). Також слід взяти до уваги те, що, дозволяючи використання у рамках кримінального переслідування доказових матеріалів, добросовісно зібраних за підсумками державних контрольно-наглядових заходів та інших адміністративних проваджень, ЄСПЛ визнає несумісним із справедливим судовим розглядом врахування інформації та відомостей з-поза кримінального провадження, якщо відповідним адміністративним провадженням зловживали для одержання цих доказів в обхід кримінального процесу (Ван Вондель проти Нідерландів (рішення про прийнятність), заява № 38258/03).

Поруч із вищевикладеними випадками, коли свобода від самовикриття не перешкоджає перевіркам та розслідуванню діяльності фізичних та юридичних осіб, право не свідчити проти себе не може слугувати підгрунтям для того, щоб позбавити адміністративні органи можливостей самостійно перевіряти діяльність фізичних та юридичних осіб, не вимагаючи від них надання певних відомостей чи документів, 3 наступним переслідуванням їх за допущені ними правопорушення. Так, з посиланням на рішення про прийнятність у справі «Кінг проти Сполученого Королівства» О. Бучинський у контексті свободи від самовикриття у податкових справах зауважує, що право на мовчання та право не свідчити проти себе не може перешкоджати витребуванню відомостей про фінансовий стан та рух коштів платника податків, якщо метою цього не $\epsilon$ доведення вчинення платником податків правопорушення до моменту направлення вимоги про надання відомостей. Покарання за сам факт ненадання відомостей на вимогу контролюючих органів не порушує жодного питання за ст. 6 Конвенції (Бучинський, 2019: 123). Більше того, за матеріалами практики ЄСПЛ немає підстав стверджувати про допущення компетентними органами держави порушення права не свідчити проти себе, якщо мало місце використання у кримінальних провадженнях тих заяв, які особа зробила під час адміністративного провадження, притому, що вона не була зобов'язана під загрозою відповідальності давати показання (Стейнс проти Сполученого Королівства (рішення про прийнятність), заява № 41552/98). Також право не свідчити проти себе не поширюється на використання в кримінальному процесі матеріалів, які можуть бути отримані від обвинуваченого незалежно від його волі примусово, як-то, наприклад, вилучення за судовою ухвалою документів, отримання зразків біоматеріалів людини для проведення аналізів тощо (Саундерс проти Сполученого Королівства, заява № 19187/91, § 69).

Таким чином, під час тлумачення адміністративно-деліктних правових норм слід враховувати недопустимість використання доказів, одержаних з порушенням свободи від самовикриття. Орган, уповноважений на розгляд справи про адміністративне правопорушення, має визнати неприйнятними докази, які особа, яка притягується до відповідальності, створила під примусом юридичного обов'язку та загрозою санкцій за його виконання. При цьому цілком допустимими мають вважатись докази, отримані уповноваженими органами, незалежно від його волі та без його участі у їх створенні; надані правопорушником добровільно, у тому числі за підсумками адміністративного провадження уповноважених органів.

Продовжуючи дослідження впливу конвенційних гарантій на тлумачення адміністративно-деліктних правових норм, звернемо увагу на інший основоположний аспект справедливого судового розгляду питання про обгрунтованість кримінального обвинувачення, яким є презумпція невинуватості. Поряд із вищезгаданими загальними процесуальними гарантіями презумпція невинуватості знайшла своє відображення у положеннях ст. 6 Конвенції, за якими кожен, кого обвинувачено у вчиненні кримінального правопорушення, вважається невинуватим доти, доки його вину не буде доведено в законному порядку.

Конкретними процесуальними вимогами, що грунтуються на презумпції невинуватості та викладаються у практиці тлумачення та застосування відповідного конвенційного положення, є:

- покладення тягаря доказування на сторону обвинувачення;

- тлумачення будь-яких сумнівів на користь обвинуваченого, що, зокрема, тягне за собою визнання неправосудним не досить мотивоване рішення про винуватість особи без належного обгрунтування цього висновку та без спростування всіх обгрунтованих сумнівів; 
- суд не має ставати до виконання своїх обов'язків із упередженим уявленням щодо того, що обвинувачений вчинив інкриміноване правопорушення;

- неможливість ставлення до особи як до винуватої після іiї виправдання або припинення відповідного провадження, незалежно від того, чи є підстави реабілітуючими або нереабілітуючими (наприклад, недопустимими визнаються покладення на особу після припинення провадження відшкодування судових витрат; iii автоматична цивільна, дисциплінарна або будь-яка інша відповідальність чи захід стягнення; публічне проголошення особи винуватою, оскільки вона була звільнена від відповідальності з реабілітуючих підстав, таких як закінчення строку давності або амністія);

- дотримання свободи від самовикриття (Дирекція юрисконсульта ЄСПЛ, 2020: 61-68).

Водночас особливостями застосування презумпції невинуватості у провадженнях про адміністративні правопорушення кримінального характеру є те, що дозволяється встановлення презумпцій винуватості у незначних кримінальних адміністративних правопорушеннях. Як приклади зазначеного наводяться презумпція відповідальності: водія за залишення місця дорожньо-транспортної пригоди або невиконання обов'язку зупинитись та повідомити поліцію про дорожньо-транспортну пригоду; роботодавця за незаконне працевлаштування іноземця; власника транспортного засобу за вчинення дорожньо-транспортного правопорушення; платника податків за податковий борг; володільця контрабандних товарів тощо. При цьому для цих презумпцій винуватості мають бути достатні підстави, а також вони мають обмежуватись для справедливого балансу між значенням питання та правом на захист (Арслан, 2019: 46-47).

Беручи до уваги вищевикладене, тлумачення та застосування адміністративно-деліктного законодавства, якщо відповідне адміністративне правопорушення та стягнення за його вчинення мають ознаки кримінального з точки зору Конвенції, має супроводжуватись дотриманням презумпції невинуватості, яка передбачає насамперед покладення тягаря доказування на сторону обвинувачення, тлумачення будь-яких сумнівів на користь обвинуваченого, а також недопустимість передчасних заяв про винуватість особи та сприйняття ії винуватою на підставі підсумків іншого адміністративного чи кримінального провадження.

Вкрай важливими для належного забезпечення справедливого судового розгляду є також положення п. «b» ч. 3 ст. 6 Конвенції про право мати час і можливості, необхідні для підготовки захисту від кримінального обвинувачення.

Конкретизуючи зміст цього положення під час вирішення питання про його застосування у справі про стверджуване порушення права на час і можливості для підготовки захисту у рамках провадження щодо допущення заявником прояву неповаги до суду, ЄСПЛ вказав на те, що ця гарантія означає, що підготовка основного захисту в його інтересах охоплює все, що є «необхідним» для підготовки основного розгляду справи судом. Обвинувачений повинен мати можливість організувати свій захист належним чином і без обмежень можливості надання суду, який розглядає справу, всіх відповідних аргументів захисту, і таким чином вплинути на результат провадження. Крім того, можливості, доступні кожному, хто обвинувачується у вчиненні кримінального правопорушення, мають включати ознайомлення - для цілей підготовки свого захисту - 3 результатами розслідувань, які проводились протягом усього провадження у справі. Питання адекватності часу та можливостей, наданих обвинуваченому, слід вирішувати в контексті обставин кожної конкретної справи (Галстян проти Вірменії, заява № 26986/03, § 84).

Наприклад, у світлі обставин справи «Корнєв і Карпенко проти України» ССПЛ встановив, що проміжок часу між правопорушенням і судовим розглядом не перевищував кількох годин, що, навіть якщо припустити, що справа була нескладною, не дозволило належним чином ознайомитися з висунутими обвинуваченнями та пред’явленими доказами, а також належним чином їх оцінити та розробити серйозну юридичну стратегію захисту. За цих обставин міжнародна судова установа констатувала, що заявниці не було надано часу та можливостей, необхідних для підготовки їі захисту (Корнєв і Карпенко проти України, заява № 17444/04, § 67-68). Аналогічним висновком підсумував ССПЛ дослідження обставин справи «Нафтова компанія «ЮКОС» проти Російської Федерації», у якій було констатовано ухилення компетентних органів держави від забезпечення належного рівня можливостей для підготовки захисту у справі, яка під час ії розгляду національними судами характеризувалась значною складністю та великим обсягом матеріалів справи. Міжнародний суд визнав недостатнім строк тривалістю 4 дні для ознайомлення зі справою обсягом близько 40000 сторінок, визначивши, що, справді, вкрай важливо провести судовий розгляд у стислий період, але це не має досягатись за рахунок звуження процесуальних прав однієї зі сторін, особливо з огляду на відносно короткий проміжок часу для розгляду справи, яка вирізняється особливою величиною та складністю. При цьому обов'язок простежити, чи достатня кількість часу була у особи, яка захищається від кримінального обвинувачення, щоб вивчити об'ємні матеріали справи для майбутніх судових розглядів, покладається на національні суди (Нафтова компанія «ЮКОС» проти Російської Федерації, заява № 14902/04, § 538-542).

Висновки. Підбиваючи підсумки дослідження впливу конвенційних гарантій справедливого судового розгляду на тлумачення адміністративно-деліктних правових норм, зазначимо, що застосовність їх визначається залежно від того, чи є кримінально-правовим характер відповідного адміністративного правопорушення та його правових наслідків, що визначається тим, що положення адміністративно-деліктного законодавства застосовується до всіх суб'єктів, має виключно репресивне та превентивне призначення, спрямоване на забезпечення суспільних інтересів, які зазвичай охороняються кримінальним правом, а засудження за вчинення відповідного правопорушення залежить від доведення вини. 3 огляду на це, одним 3 найбільш важливих завдань тлумачення адміністративно-деліктних правових норм у справах про адміністративні правопорушення із 
кримінально-правовою природою є забезпечення дотримання конвенційних гарантій справедливого судового розгляду, якими передбачено, зокрема: 1) змагальність судового розгляду та рівність його учасників, які вимагають того, щоб «кримінальне обвинувачення» під час адміністративно-деліктного судочинства підтримував прокурор або інша уповноважена посадова особа, а також того, щоб особа мала можливість ознайомитись з усіма матеріалами справи та можливість одержати докази за допомогою суду, крім випадків, коли докази не мають значення для вирішення справи або заява про їх витребування не супроводжується належним обгрунтуванням; 2) обгрунтованість судових рішень, що покладає на суд обов'язок оцінити доводи та докази особи, яка притягується до відповідальності, що можуть вплинути на висновок про іiі винуватість та адміністративно-деліктні наслідки вчиненого нею адміністративного правопорушення, керуючись при цьому стандартом доказування «поза розумним сумнівом»; 3) непорушність свободи від самовикриття, що унеможливлює визнання неприйнятними доказів, які особа, яка притягується до відповідальності, створила під примусом юридичного обов'язку та загрозою санкцій за його виконання; 4) дотримання презумпції невинуватості, яка передбачає насамперед покладення тягаря доказування на сторону обвинувачення, тлумачення будь-яких сумнівів на користь обвинуваченого, а також недопустимість передчасних заяв про винуватість особи та сприйняття іiі винуватою на підставі підсумків іншого адміністративного чи кримінального провадження; 5) надання особі, яка притягується до відповідальності, часу і можливостей, необхідних для підготовки захисту, який полягає, зокрема, в ознайомленні з висунутими обвинуваченнями та наявними доказами, а також у їх належній оцінці та визначенні шляхів захисту від обвинувачення, у тому числі з використанням допомоги адвоката.

\section{Список використаних джерел:}

1. Abdullayev v. Azerbaijan, Application No. 6005/08, 7 March 2019. URL: http://hudoc.echr.coe.int/eng?i=001-191357.

2. Arslan M. Procedural Guarantees for Criminal and Administrative Criminal Sanctions: A Study of the European Convention on Human Rights. (Vol. 4) Schriftenreihe des Max-Planck-Instituts für ausländisches und internationales Strafrecht: Beiträge zum Sicherheitsrecht. Freiburg i. Br.: Max-Planck-Institut für ausländisches und internationales Strafrecht, Forschungsgruppe "Architektur des Sicherheitsrechts" (ArchiS). 2019. DOI: 10.30709/archis-2019-4.

3. Avşar v. Turkey, Application No. 25657/94, 10 July 2001. URL: http://hudoc.echr.coe.int/eng?i=001-59562.

4. de Moor-van Vugt A. Administrative sanctions in EU law. Review of European Administrative Law. 2012. 5(1). Pp. 5-41. URL: http://www.uitgeverijparis.nl/online/pdf/6123.pdf.

5. European Court of Human Rights' Guide on Article 6 of the European Convention on Human Rights "Right to a fair trial (criminal limb)". Updated on 30 April 2019. URL: https://www.echr.coe.int/Documents/Guide_Art66_criminal_ENG.pdf.

6. Kansal v. the United Kingdom, Application No. 21413/02, 27 April 2004. URL: http://hudoc.echr.coe.int/eng?i=001-61745.

7. Marttinen v. Finland, Application No. 19235/03, 21 April 2009. URL: http://hudoc.echr.coe.int/eng?i=001-92233.

8. Staines v. The United Kingdom (dec.), Application No. 41552/98, 16 May 2000. URL: http://hudoc.echr.coe.int/ eng? $\mathrm{i}=001-5291$.

9. Van Vondel v. the Netherlands (dec.), Application No. 38258/03, 23 March 2006. URL: http://hudoc.echr.coe.int/ eng? $\mathrm{i}=001-82962$.

10. Бучинський О.Й. Застосування практики Європейського суду з прав людини під час вирішення податкових спорів : дис. ... канд. юрид. наук : 12.00.07. Ун-т мит. справи та фінансів. Дніпро, 2019. 192 с.

11. Галстян против Армении, жалоба № 26986/03, 15 ноября 2007 года. URL: https://precedent.in.ua/2016/04/08/galstyanprotyv-armenyy/.

12. Діденко А. Застосування практики ЄСПЛ при розгляді справ про адміністративні правопорушення. ЛIГА.net. 2020. URL: https://blog.liga.net/user/adidenko/article/36907.

13. Довідник із застосування статті 6 Свропейської конвенції з прав людини «Право на справедливий суд» (кримінально-процесуальний аспект). Дата оновлення 31 грудня 2013 року. URL: https://www.echr.coe.int/Documents/ Guide_Art_6_UKR.pdf.

14. Кобець проти України, заява № 16437/04, 14 лютого 2008 року. URL: https://zakon.rada.gov.ua/laws/show/974 320/ conv\#Text.

15. Корнєв і Карпенко проти України, заява № 17444/04, 21 жовтня 2010 року. URL: https://zakon.rada.gov.ua/laws/ show/974_637/conv\#Text.

16. ОАО «Нефтяная компания «ЮКОС» против России, жалоба № 14902/04, 31 июля 2014 года. URL: http://hudoc.echr.coe.int/webservices/content/docx/001-145730.

17. Саундерс против Соединенного Королевства, жалоба № 19187/91, 17 декабря 1996 г. (краткое неофициальное изложение обстоятельств дела - извлечение из судебного решения). URL: https://precedent.in.ua/2016/04/09/saundersprotyv-soedynennogo-korole/.

18. Серявін та інші проти України, заява № 4909/04, 10 лютого 2010 року. URL: https://zakon.rada.gov.ua/laws/ show/974 672\#Text.

19. Чжан проти України, заява № 6970/15, 13 листопада 2018 року. URL: https://zakon.rada.gov.ua/laws/show/974_ d21\#Text.

\section{References:}

1. Abdullayev v. Azerbaijan, No. 6005/08, 2019, ECHR. Retrieved from: http://hudoc.echr.coe.int/eng?i=001-191357.

2. Arslan, M. (2019). Procedural Guarantees for Criminal and Administrative Criminal Sanctions: A Study of the European Convention on Human Rights. (Vol. 4) Schriftenreihe des Max-Planck-Instituts für ausländisches und internationales Strafrecht: Beiträge zum Sicherheitsrecht. Freiburg i.Br.: Max-Planck-Institut für ausländisches und internationales Strafrecht, Forschungsgruppe “Architektur des Sicherheitsrechts” (ArchiS). DOI: 10.30709/archis-2019-4. 
3. Avşar v. Turkey, No. 25657/94, 2001, ECHR. Retrieved from: http://hudoc.echr.coe.int/eng?i=001-59562.

4. de Moor-van Vugt A. (2012). Administrative sanctions in EU law. Review of European Administrative Law. 5(1). Pp. 5-41. Retrieved from: http://www.uitgeverijparis.nl/online/pdf/6123.pdf.

5. Directorate of the Jurisconsult of the European Court of Human Rights (2019). Guide on Article 6 of the European Convention on Human Rights "Right to a fair trial (criminal limb)". Retrieved from: https://www.echr.coe.int/Documents/ Guide_Art 6 criminal_ENG.pdf.

6. Kansal v. the United Kingdom, No. 21413/02, 2004, ECHR. Retrieved from: http://hudoc.echr.coe.int/eng?i=001-61745.

7. Marttinen v. Finland, No. 19235/03, 2009, ECHR. http://hudoc.echr.coe.int/eng?i=001-92233.

8. Staines v. The United Kingdom (dec.), No. 41552/98, 2000, ECHR. Retrieved from: http://hudoc.echr.coe.int/ eng? $\mathrm{i}=001-5291$.

9. Van Vondel v. the Netherlands (dec.), No. 38258/03, 2006. ECHR. Retrieved from: http://hudoc.echr.coe.int/ eng?i=001-82962.

10. Buchynskyi, O.Y. (2019). Zastosuvannia praktyky Yevropeiskoho sudu z prav liudyny pid chas vyrishennia podatkovykh sporiv [Application of the case-law of the European Court of Human Rights in tax disputes resolution]. Dissertation of Candidate of Legal Sciences. University of Customs and Finance, Dnipro, Ukraine. Retrieved from: http://umsf.dp.ua/.

11. Galstyan v. Armenia, No. 26986/03, 2007, ECHR. Retrieved from: https://precedent.in.ua/2016/04/08/galstyan-protyv-armenyy/.

12. Didenko, A. Zastosuvannia praktyky YeSPL pry rozghliadi sprav pro administratyvni pravoporushennia [ECtHR case-law application in administrative sanctioning proceedings]. Retrieved from: https://blog.liga.net/user/adidenko/article/36907.

13. Dovidnyk iz zastosuvannia statti 6 Yevropeiskoi konventsii z prav liudyny "Pravo na spravedlyvyi sud" (kryminalnoprotsesualnyi aspekt) [Guide on Article 6 of the European Convention on Human Rights "Right to a fair trial (criminal limb)"]. Updated on 13 December 2013. Retrieved from: https://www.echr.coe.int/Documents/Guide_Art_6_UKR.pdf.

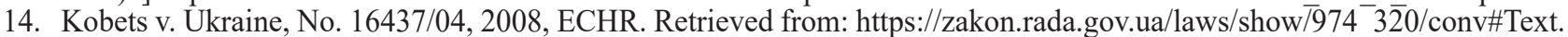

15. Kornev and Karpenko v. Ukraine, No. 17444/04, 2010, ECHR. Retrieved from: https://zakon.rada.gov.ua/laws/ show/974 637/conv\#Text.

16. OAO Neftyanaya Kompaniya Yukos v. Russia, No. 14902/04, 2014, ECHR. Retrieved from: http://hudoc.echr.coe.int/ webservices/content/docx/001-145730.

17. Saunders v. United Kingdom (legal summary), No. 19187/91, 1996, ECHR. Retrieved from: https://precedent. in.ua/2016/04/09/saunders-protyv-soedynennogo-korole/.

18. Seryavin and Others v. Ukraine, No. 4909/04, 2010, ECHR. Retrieved from: https://zakon.rada.gov.ua/laws/ show/974 672\#Text.

19. Zhang v. Ükraine, No. 6970/15, 2018, ECHR. Retrieved from: https://zakon.rada.gov.ua/laws/show/974_d21\#Text.

DOI https://doi.org/10.51647/kelm.2020.3.1.44

\title{
ІСТОРІЯ СТАНОВЛЕННЯ ІНСТИТУТУ СПЕЦАЛЬНОЇ КОНФІСКАЦІЇ У ЗАКОНОДАВСТВІ УКРАЇНИ ТА В ОКРЕМИХ ЄВРОПЕЙСЬКИХ ДЕРЖАВАХ
}

\author{
Анастасія Лукомська \\ аспірант кафедри кримінального процесу та криміналістики \\ Академії адвокатури України (Київ, Україна) \\ ORCID ID: 0000-0001-9159-5553
}

\begin{abstract}
Анотація. Визначення Україною свого вектору зовнішньополітичного розвитку на користь Свропейського Союзу зумовило чимало процесів, серед яких і адаптація національного законодавства до європейських стандартів. Одним із кроків, спрямованих на адаптацію законодавства, стало законодавче закріплення інституту спеціальної конфіскації майна. Адаптація законодавства - це тривалий і кропіткий процес постійних змін, доповнень, неможливий без аналізу історичного досвіду регламентування та застосування спеціальної конфіскації. Дослідження генезису інституту спеціальної конфіскації дає змогу сформулювати основні принципи, які лежать в основі інституту. Аналіз історичного досвіду регламентування спеціальної конфіскації в окремих європейських державах дає змогу сформулювати європейський концепт спеціальної конфіскації, що є необхідним елементом євроінтеграційного процесу.

Ключові слова: спеціальна конфіскація, загальна конфіскація, кримінальне покарання, інші заходи кримінально-правового характеру, захід кримінально-правового впливу, речові докази.
\end{abstract}

\section{HISTORY OF ESTABLISHMENT OF THE INSTITUTE OF SPECIAL CONFISCATION IN THE LEGISLATION OF UKRAINE AND OF CERTAIN EUROPEAN STATES}

\author{
Anastasia Lukomska \\ Graduate Student at the Department of Criminal Procedure and Criminology \\ Academy of Advocacy of Ukraine (Kyiv, Ukraine) \\ ORCID ID: 0000-0001-9159-5553
}

\begin{abstract}
Ukraine's determination of its vector of foreign policy development in favor of the European Union has led to many processes, including the adaptation of national legislation to the European standards. One of the steps aimed at adapting
\end{abstract}

